\title{
Occurrence of oral and pharyngeal cancers in textile workers
}

\author{
E. MOSS and W. R. LEE \\ Department of Occupational Health, University of Manchester
}

\begin{abstract}
Moss, E. and Lee, W. R. (1974). British Journal of Industrial Medicine, 31, 224-232. Occurrence of oral and pharyngeal cancers in textile workers. The occupations of male textile workers who died of oral and pharyngeal cancers in the five years 1959-63 have been examined to discover whether the high incidence of oral cancer in these workers noted by the Office of Population Censuses and Surveys (1972) is associated with particular textile occupations or fibres.

There was a $77 \%$ excess of deaths from these cancers in male textile workers as a whole compared with the male population of England and Wales, the excess being significant at the $0.1 \%$ level. An excess occurred in each of the three sites tongue (ICD 141), mouth (ICD 143, 144), and pharynx (ICD 145-148) and is significant at the $5 \%$ level in the first two sites but not in the third.

Fibre preparers had an excess of $330 \%$ which is significant at the $0.01 \%$ level. Weavers and knitters had a deficit of $32 \%$ and the remaining three groups had moderate excesses of from 32 to $85 \%$, none of the four being statistically significant.

In the 1951 census there were 8414 male cotton workers and 14723 male wool workers engaged in fibre preparing. There was one death from oral cancer in cotton fibre preparers and 18 deaths in wool fibre preparers. The difference is significant at the $1 \%$ level. The difference is also significant for the individual sites pharynx and tongue but not mouth.
\end{abstract}

In Studies on Medical and Population Subjects No. 23 -Oral Cancer ${ }^{1}$ in England and Wales published in 1972 by the Office of Population Censuses and Surveys, a high incidence of oral cancer in male textile workers was noted and it was suggested that 'it would be of great interest to look further into this'. Excesses were found in both mortality and morbidity.

Acheson, Cowdell, and Rang (1972) found some evidence of an excess of adenocarcinoma of the nasal cavity and sinuses in male and female workers in the textile and clothing industries in England and Wales.

The purpose of the present paper is to examine more closely the available data to discover whether the high incidence noted in the oral cancer study is

1 The title is Oral Cancer, but the pharynx was also included in the Study. associated with particular textile occupations or fibres.

\section{Material and method}

The individual records on which Study No. 23 was based were obtained from the Registrar General. There were 56 male textile workers aged 15-74 who died of oral or pharyngeal cancer in the five years 1959-63. There were also records of eight single women textile workers who died of the same diseases in the same period, and similarly 16 married women classified according to the occupation of their husbands who were textile workers. This group of married women was not used in our study as their own occupations were not recorded.

The oral and pharyngeal cancer registrations of 46 male and 27 female textile workers in the 13 cancer registries in England and Wales for the years 1966-68 were also provided by the Registrar General. The excess morbidity ratios noted in Study No. 23 had been based on about two-thirds of the 1966-67 male cancer registrations. 
Records of the deaths in 1970-71 of 16 male and 21 female textile workers aged 15 and over were also available. The 21 females included 16 single women and five married women who were themselves textile workers. There were also 13 wives of textile workers who were not themselves textile workers.

The causes of death and of morbidity were classified according to the International Classification of Diseases (ICD) (7th Revision) in use by the Registrar General at the date of death (1959-63) and were grouped as follows:

$\begin{array}{lc}\text { Malignant neoplasm of } & \text { ICD Code No. } \\ \text { Tongue } & 141 \\ \text { Mouth (floor, other parts } & 143,144 \\ \quad \text { and unspecified) } & \\ \text { Pharynx } & 145 \\ \text { Oro- (tonsils) } & 146 \\ \text { Naso- } & 147 \\ \text { Hypo- } & 148\end{array}$

In this study ICD 145, oral mesopharynx (tonsils and fauces), has been included in the pharynx group. In the ICD 8th Revision (1965) tonsils and fauces are classified as oropharynx. Also Easson and Russell (1968) have stated that 'Tonsillar tumours are defined as of pharyngeal origin'. In our analysis the salivary gland (ICD 142) has been excluded as belonging to a different system. Malignant neoplasms of the salivary gland accounted for the deaths of seven male and four female textile workers and for seven male and three female registrations in all, and are not included in the numbers for oral and pharyngeal cancers given above.

There were no deaths of textile workers from malignant neoplasms of the lip (ICD 140).

The textile occupations were classified in the Occupation Unit groups in Occupation Order X (Textile Workers) of the Office of Population Censuses and Surveys Classification of Occupations, 1960, as used for the 1961 census. Because the numbers are so small unit groups were combined where the occupations are of a generally similar nature:

Unit group
$\left\{\begin{array}{l}100 \\ 101 \\ 102 \\ 103 \\ 104 \\ 105 \\ 106\end{array}\right.$
$\left\{\begin{array}{l}107 \\ 108\end{array}\right.$

In the majority of the death records the fibre worked with was mentioned specifically or identifiable by other evidence. For our analysis the few instances where the fibre could not be determined have been combined with those in which fibres other than cotton or wool were mentioned, e.g., silk, nylon, and rayon. The distribution according to fibre is shown in Table 1. The registrations were less certain than the mortality records with legard to the fibre used.

During the period relevant to this survey nearly all textile operatives in England and Wales worked with
TABLE 1

Distribution of Numbers in SURVey ACCORDING TO FIBRE WORKED WITH

\begin{tabular}{l|cc|cc}
\hline \multirow{2}{*}{\multicolumn{1}{c|}{ Fibre }} & \multicolumn{2}{|c|}{ Deaths } & \multicolumn{2}{c}{ Registrations } \\
\cline { 2 - 5 } & Male & Female & Male & Female \\
\hline Cotton & 27 & 18 & 28 & 11 \\
Wool & 32 & 5 & 4 & 3 \\
Other and not known & 13 & 6 & 14 & 13 \\
\hline \multicolumn{1}{c}{ Total } & 72 & 29 & 46 & 27 \\
& & & & \\
\hline
\end{tabular}

cotton or wool. In 1951, for example, the proportions for male fibre preparers, spinners, and weavers combined were cotton $45 \%$, wool $42 \%$, other $13 \%$. The proportions in other textile occupations would be similar.

As far as possible the numbers of deaths from and occurrences of malignant neoplasms at the different sites have been compared with the numbers of textile workers in the various occupational categories as shown by the censuses of 1951 and 1961, bearing in mind that occupational cancers take some years to develop. There was no census in 1941.

\section{Results}

\section{Proportionate mortalities}

In Table 2 the numbers of oral and pharyngeal deaths of male textile workers in England and Wales 1959-63 aged 15-64 from the individual records are compared with the corresponding numbers of deaths from malignant neoplasms at all sites (ICD 140-205) taken from the Registrar General's Decennial Supplement, England and Wales, 1961, Occupational Mortality Tables (Registrar General, 1971). The proportion of deaths (tongue, mouth, and pharynx combined) in fibre preparers is significantly higher than in textile workers (all occupations combined) $(P=0.03)$. The proportion is appreciably lower in weavers and knitters combined (not significant at the $5 \%$ level). In the other occupational sub-groups the proportions are closer to the proportion for all occupations combined.

In the fibre preparers the proportions are higher in the tongue (not statistically significant) and pharynx $(P=0.02)$ but not in the mouth.

\section{Observed and expected deaths age-adjusted}

In Table 3 the observed numbers of oral and pharyngeal deaths of male textile workers in England and Wales 1959-63 aged 15-64 from the individual records are compared with the expected numbers based on the corresponding deaths of all males, ageadjusted. The distributions in 10-year age groups of the 1961 census population of the textile workers in each occupational sub-group were obtained from 
TABLE 2

Proportionate Mortalities of Male Textile Workers aged 15-64, England and Wales, 1959-63

\begin{tabular}{|c|c|c|c|c|c|c|}
\hline \multirow{2}{*}{$\begin{array}{c}\text { Cause of death } \\
\begin{array}{l}\text { Malignant } \\
\text { neoplasm }\end{array}\end{array}$} & \multicolumn{6}{|c|}{ Number of deaths and deaths as percentage of deaths from malignant neoplasms of all sites } \\
\hline & $\begin{array}{c}\text { Fibre } \\
\text { preparers }\end{array}$ & $\begin{array}{c}\text { Spinners, } \\
\text { winders, } \\
\text { warpers, etc. }\end{array}$ & $\begin{array}{l}\text { Weavers, } \\
\text { knitters }\end{array}$ & $\begin{array}{l}\text { Bleachers, } \\
\text { dyers, } \\
\text { finishers }\end{array}$ & Miscellaneous & $\begin{array}{c}\text { All textile workers } \\
(\text { male })\end{array}$ \\
\hline $\begin{array}{l}\text { All sites } \\
\text { (ICD 140-205) }\end{array}$ & 281 & 290 & 293 & 253 & 365 & 1482 \\
\hline $\begin{array}{l}\text { Tongue } \\
\text { Mouth } \\
\text { Pharynx }\end{array}$ & $\begin{array}{c}3(1.1 \%) \\
1(0.4 \%) \\
7(2.5 \%) \\
(P=0.02)\end{array}$ & $\begin{array}{l}2(0.7 \%) \\
1(0.3 \%) \\
2(0.7 \%)\end{array}$ & $\begin{array}{l}1(0 \cdot 3 \%) \\
1(0 \cdot 3 \%) \\
1(0 \cdot 3 \%)\end{array}$ & $\begin{array}{l}2(0.8 \%) \\
2(0.8 \%) \\
2(0.8 \%)\end{array}$ & $\begin{array}{l}1(0.3 \%) \\
3(0.8 \%) \\
2(0.5 \%)\end{array}$ & $\begin{array}{r}9(0.6 \%) \\
8(0.5 \%) \\
14(0.9 \%)\end{array}$ \\
\hline $\begin{array}{l}\text { Tongue, mouth, } \\
\text { and pharynx } \\
\text { combined }\end{array}$ & $\begin{array}{l}11(3.9 \%) \\
(P=0.03)\end{array}$ & $5(1.7 \%)$ & $3(1 \cdot 0 \%)$ & $6(2 \cdot 4 \%)$ & $6(1 \cdot 6 \%)$ & $31(2 \cdot 1 \%)$ \\
\hline
\end{tabular}

the Occupational Mortality Tables in the 1961 Decennial Supplement.

The $77 \%$ excess of oral and pharyngeal cancers combined in male textile workers as a whole is highly significant $(P=0.001)$. The excesses occur in all three sites.

In the occupational sub-groups, weavers and knitters had a deficit of $32 \%$ (not statistically sig- nificant). The fibre preparers had a large excess of $330 \%$, which is highly significant $(P<0.0001)$, and the remaining three sub-groups had moderate excesses ranging from 32 to $85 \%$ which are not statistically significant.

The fibre preparers had excesses at all three sites, significant in the tongue $(346 \%, P=0.03)$ and highly significant in the pharynx $(404 \%, \mathrm{P}<0.001)$.

TABLE 3

Observed (O) and Expected (E) Deaths from Oral and Pharyngeal Cancers of Male Textile Workers, Aged 15-64, in ENGland and Wales, 1959-63, Age-ADJusted

\begin{tabular}{|c|c|c|c|c|c|c|c|}
\hline \multicolumn{2}{|c|}{$\begin{array}{c}\text { Cause of death } \\
\text { Malignant } \\
\text { neoplasm }\end{array}$} & \multirow{2}{*}{$\begin{array}{c}\begin{array}{c}\text { Fibre } \\
\text { preparers }\end{array} \\
3 \\
0.67 \\
4.46 \\
0.03\end{array}$} & \multirow{2}{*}{ 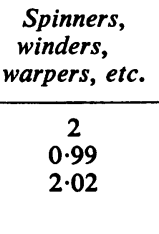 } & \multirow{2}{*}{$\begin{array}{c}\begin{array}{c}\text { Weavers, } \\
\text { knitters }\end{array} \\
1 \\
1 \cdot 15 \\
0.87\end{array}$} & \multirow{2}{*}{$\begin{array}{c}\begin{array}{c}\text { Bleachers, } \\
\text { dyers, } \\
\text { finishers }\end{array} \\
2 \\
0.85 \\
2.34\end{array}$} & \multirow{2}{*}{$\begin{array}{c}\text { Miscellaneous } \\
1 \\
0.93 \\
1.07\end{array}$} & \multirow{2}{*}{$\begin{array}{c}\begin{array}{c}\text { All textile workers } \\
\text { (male) }\end{array} \\
9 \\
4.59 \\
1.96 \\
0.04\end{array}$} \\
\hline Tongue & $\begin{array}{l}\mathbf{O} \\
\mathbf{E} \\
\mathbf{O} / \mathbf{E} \\
\mathbf{P}\end{array}$ & & & & & & \\
\hline Mouth & $\begin{array}{l}\mathbf{O} \\
\mathbf{E} \\
\mathbf{O} / \mathbf{E} \\
\mathbf{P}\end{array}$ & $\begin{array}{c}1 \\
0.50 \\
1.98\end{array}$ & $\begin{array}{c}1 \\
0 \cdot 75 \\
1 \cdot 34\end{array}$ & $\begin{array}{c}1 \\
0 \cdot 85 \\
1 \cdot 17\end{array}$ & $\begin{array}{c}2 \\
0 \cdot 64 \\
3 \cdot 11\end{array}$ & $\begin{array}{c}3 \\
0.71 \\
4.21 \\
0.04\end{array}$ & $\begin{array}{c}8 \\
3 \cdot 45 \\
2 \cdot 32 \\
0 \cdot 02\end{array}$ \\
\hline Pharynx & $\begin{array}{l}\mathbf{O} \\
\mathbf{E} \\
\mathbf{O} / \mathbf{E} \\
\mathbf{P}\end{array}$ & $\begin{array}{c}7 \\
1.39 \\
5.04 \\
<0.001\end{array}$ & $\begin{array}{c}2 \\
2 \cdot 04 \\
0.98\end{array}$ & $\begin{array}{c}1 \\
2 \cdot 39 \\
0 \cdot 42\end{array}$ & $\begin{array}{c}2 \\
1 \cdot 76 \\
1 \cdot 14\end{array}$ & $\begin{array}{c}2 \\
1.93 \\
1.04\end{array}$ & $\begin{array}{l}14 \\
9 \cdot 51 \\
1 \cdot 47\end{array}$ \\
\hline $\begin{array}{l}\text { Tongue, } \\
\text { mouth and } \\
\text { pharynx } \\
\text { combined }\end{array}$ & $\begin{array}{l}\mathbf{O} \\
\mathrm{E} \\
\mathbf{O} / \mathbf{E} \\
\mathbf{P}\end{array}$ & $\begin{array}{c}11 \\
2 \cdot 56 \\
4 \cdot 30 \\
<0.0001\end{array}$ & $\begin{array}{c}5 \\
3 \cdot 78 \\
1 \cdot 32\end{array}$ & $\begin{array}{c}3 \\
4 \cdot 39 \\
0 \cdot 68\end{array}$ & $\begin{array}{c}6 \\
3 \cdot 25 \\
1 \cdot 85\end{array}$ & $\begin{array}{c}6 \\
3 \cdot 57 \\
1 \cdot 68\end{array}$ & $\begin{array}{c}31 \\
17 \cdot 52 \\
1 \cdot 77 \\
0 \cdot 001\end{array}$ \\
\hline
\end{tabular}

$\mathrm{E}>5 \mathrm{P}$ based on $\chi^{2} ; \mathrm{E}<5 \mathrm{P}$ based on Poisson distribution $P$ is quoted only when it is less than 0.05 
TABLE 4

Number of Deaths of Male Textile Workers from Oral and Pharyngeal Cancers in ENGLAND AND WALES

(a) 1959-63, aged 15-64

(b) , aged 65-74

(c) 1970-71, aged 15 and over

(d) $($ a) + (b) + (c)

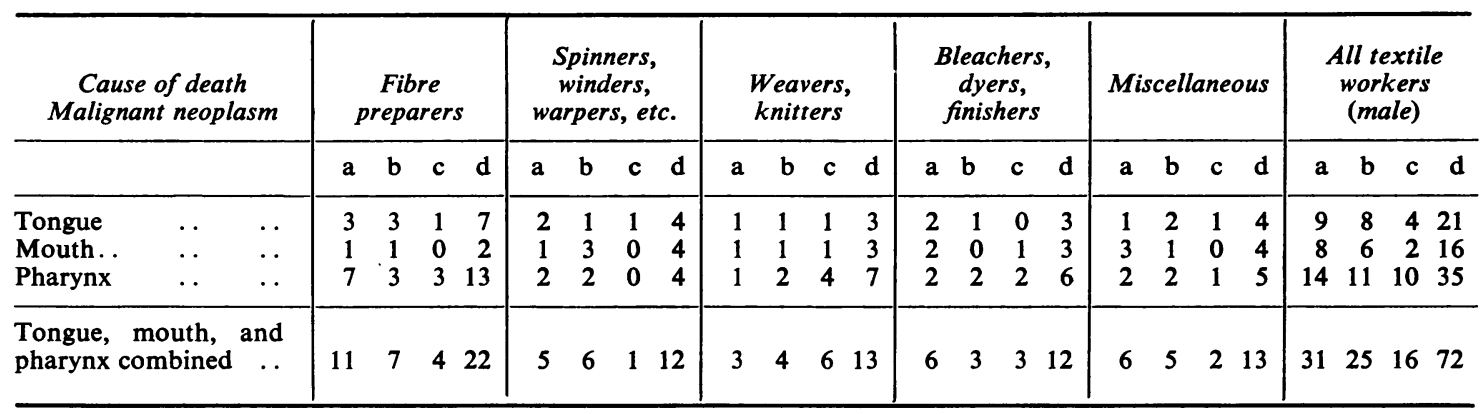

Numbers of deaths and of workers in occupational sub-groups

In order to make use of the deaths in men aged 65-74 in 1959-63 and aged 15 and over in 1970-71 another comparison has been made. The distribution of the additional deaths among the occupational sub-groups and the sites of the malignant neoplasms is broadly similar to that of the 1959-63 deaths aged 15-64 (Table 4). Therefore all the deaths have been combined and compared with the 1951 census populations of the textile workers (aged 20-64) in the various occupational sub-groups. These census

TABLE 5

Deaths of Male Textile Workers, 1959-63, Aged 15-74, and 1970-71, Aged 15 AND over, COMPARED WITH NUMBERS WORKING IN 1951, AGED 20-64

\begin{tabular}{|c|c|c|c|c|c|c|c|}
\hline \multirow{3}{*}{\multicolumn{2}{|c|}{$\begin{array}{c}\text { Cause of death } \\
\begin{array}{l}\text { Malignant } \\
\text { neoplasm }\end{array}\end{array}$}} & $\begin{array}{c}\text { Fibre } \\
\text { preparers }\end{array}$ & $\begin{array}{c}\text { Spinners, } \\
\text { winders, } \\
\text { warpers, etc. }\end{array}$ & $\begin{array}{l}\text { Weavers, } \\
\text { knitters }\end{array}$ & $\begin{array}{c}\text { Bleachers, } \\
\text { dyers, } \\
\text { finishers }\end{array}$ & Miscellaneous & $\begin{array}{l}\text { All textile workers } \\
\text { (male) }\end{array}$ \\
\hline & & \multirow{2}{*}{\multicolumn{6}{|c|}{$\begin{array}{c}\text { Number working in } 1951 \text {, aged } 20-64 \\
48827\end{array}$}} \\
\hline & & & & & & & \\
\hline Tongue & $\begin{array}{l}\mathbf{O} \\
\mathbf{E} \\
\mathbf{O} / \mathbf{E} \\
\mathbf{P}\end{array}$ & $\begin{array}{c}7 \\
3 \cdot 10 \\
2 \cdot 26 \\
0 \cdot 04\end{array}$ & $\begin{array}{c}4 \\
5 \cdot 34 \\
0 \cdot 75\end{array}$ & $\begin{array}{c}3 \\
5 \cdot 85 \\
0 \cdot 51\end{array}$ & $\begin{array}{c}3 \\
4 \cdot 73 \\
0 \cdot 63\end{array}$ & $\begin{array}{c}4 \\
1.98 \\
2 \cdot 02\end{array}$ & $\begin{array}{c}21 \\
21 \cdot 00\end{array}$ \\
\hline Mouth & $\begin{array}{l}\mathbf{O} \\
\mathbf{E} \\
\mathbf{O} / \mathrm{E} \\
\mathbf{P}\end{array}$ & $\begin{array}{c}2 \\
2 \cdot 36 \\
0 \cdot 85\end{array}$ & $\begin{array}{c}4 \\
4.07 \\
0.98\end{array}$ & $\begin{array}{c}3 \\
4.45 \\
0.67\end{array}$ & $\begin{array}{c}3 \\
3.60 \\
0.83\end{array}$ & $\begin{array}{c}4 \\
1.52 \\
2.63\end{array}$ & $\begin{array}{r}16 \\
16 \cdot 00\end{array}$ \\
\hline Pharynx & $\begin{array}{l}\mathbf{O} \\
\mathbf{E} \\
\mathbf{O} / \mathbf{E} \\
\mathbf{P}\end{array}$ & $\begin{array}{c}13 \\
5 \cdot 16 \\
2 \cdot 52 \\
<0 \cdot 001\end{array}$ & $\begin{array}{c}4 \\
8 \cdot 89 \\
0 \cdot 45\end{array}$ & $\begin{array}{c}7 \\
9.75 \\
0.72\end{array}$ & $\begin{array}{c}6 \\
7 \cdot 88 \\
0 \cdot 76\end{array}$ & $\begin{array}{c}5 \\
3 \cdot 31 \\
1 \cdot 51\end{array}$ & $\begin{array}{c}35 \\
34 \cdot 99\end{array}$ \\
\hline $\begin{array}{l}\text { Tongue, } \\
\text { mouth, and } \\
\text { pharynx } \mathbf{O} \\
\text { combined }\end{array}$ & $\begin{array}{l}O \\
d E \\
O / E \\
P\end{array}$ & $\begin{array}{c}22 \\
10.62 \\
2.07 \\
<0.001\end{array}$ & $\begin{array}{c}12 \\
18 \cdot 28 \\
0 \cdot 66\end{array}$ & $\begin{array}{c}13 \\
20 \cdot 07 \\
0.65\end{array}$ & $\begin{array}{r}12 \\
16 \cdot 21 \\
0 \cdot 74\end{array}$ & $\begin{array}{c}13 \\
6 \cdot 81 \\
1.91 \\
0.02\end{array}$ & $\begin{array}{r}72 \\
71 \cdot 99\end{array}$ \\
\hline
\end{tabular}

E $>5$ P based on $\chi^{2} ; \quad \mathrm{E}<5 \mathrm{P}$ based on Poisson distribution

$P$ given only when less than 0.05 
populations have been taken from the Occupational Mortality Tables of the Registrar General's Decennial Supplement, England and Wales, 1951 (Registrar General, 1958), and have been rearranged to some extent to conform with the 1960 Classification of Occupations used elsewhere in this paper.

All but one of the 72 workers whose deaths have been used in this comparison were aged 20-64 in 1951.

In Table 5 the textile workers are not being compared with the non-textile working population, but the various textile occupational sub-groups are being compared with one another. The expected numbers in each occupational sub-group are obtained by distributing the total number of deaths at each site among the sub-groups in proportion to the numbers working in each sub-group in 1951. There is a highly significant excess of oral and pharyngeal cancers combined in fibre preparers compared with all textile workers $(P<0.001)$. The excesses are statistically significant in the tongue $(P=0.04)$ and highly significant in the pharynx $(P<0.001)$ but there was no excess in the mouth. There was a significant excess of oral and pharyngeal cancers combined in the sub-group of miscellaneous occupations $(P=0.02)$. This was made up of excesses at each of the three sites, tongue, mouth, and pharynx, none of which was statistically significant.

In this comparison the excesses in fibre preparers and miscellaneous occupations are necessarily balanced by deficits elsewhere and these were found to be distributed fairly evenly in the remaining three occupational sub-groups which had overall deficits of about $30 \%$ made up of deficits at each of the three sites. None of these deficits is statistically significant.

Although many of the workers whose deaths have been used in this comparison were of working age in 1931 , some were not. Also there was a large reduction in the numbers of textile workers between 1931 and 1951, and to a much smaller extent between 1951 and 1961 , so that many of the textile workers of 1931 who survived to 1959 and later would have found other jobs and would not be recorded as textile workers. For these reasons no comparison with the census population of 1931 has been made.

Deaths in the retired population aged $65-74$ in 1959-63 should not be compared with the number of workers aged 15-64 in 1961. The valid comparison with the census working population of 1961 has been made in Table 3 .

\section{Type of fibre worked with}

In the comparisons made so far the type of fibre with which the textile operative worked has been ignored. The 1961 census populations published by the Registrar General do not classify the textile occupations according to fibre. The 1951 census identified the textile fibre worked with only for:

(i) fibre preparers, including strippers and grinders

(ii) spinners, doublers, piecers and twisters but excluding winders and reelers

(iii) weavers, including carpet weavers as wool.

In Table 6 the numbers of deaths of male textile workers in these occupations are compared with the numbers working in them in 1951 divided according to fibre. All but one of the $\mathbf{4 3}$ deaths in this table were of workers who were aged 20-64 years in 1951 and the numbers of deaths in cotton spinners and weavers, although rather more than would be expected from the numbers working in 1951, are too small for the excesses to be statistically significant. In the fibre preparers, however, there were 18 deaths in wool workers and only one in cotton workers.

TABLE 6

Deaths of Male Textile Workers, 1959-63, Aged 15-74, AND 1970-71, Aged 15 aNd OVer, COMPARED WITH NUMBERS WORKING IN 1951, AGED 20-64, ACCORDING TO FibRE WORKED WITH

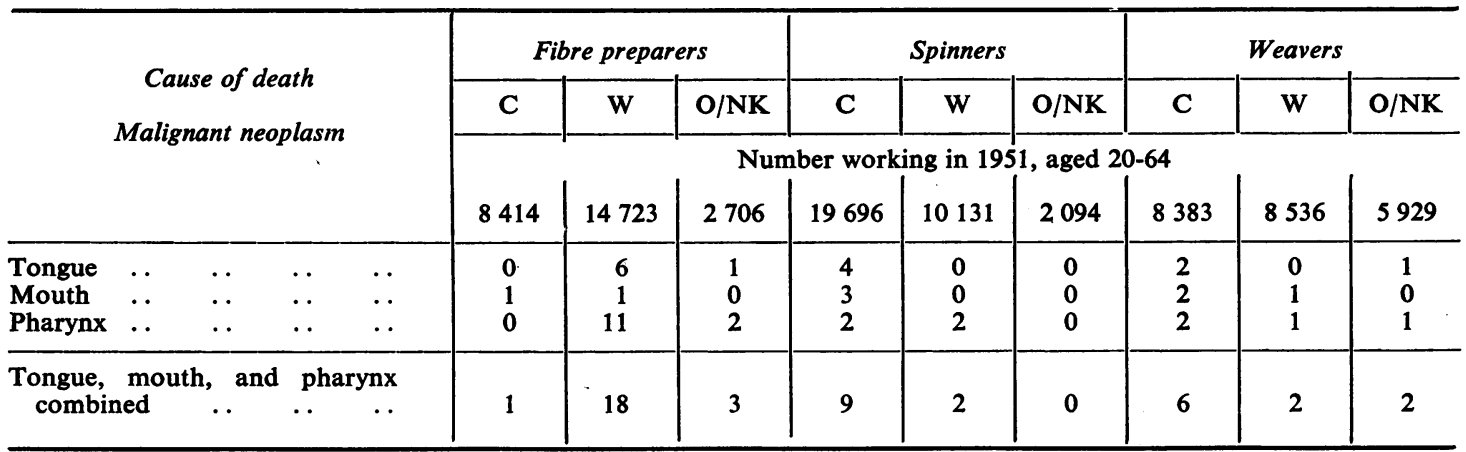

$\mathrm{C}=$ cotton $; \mathrm{W}=$ wool $; \mathrm{O} / \mathrm{NK}=$ other fibre or not known 


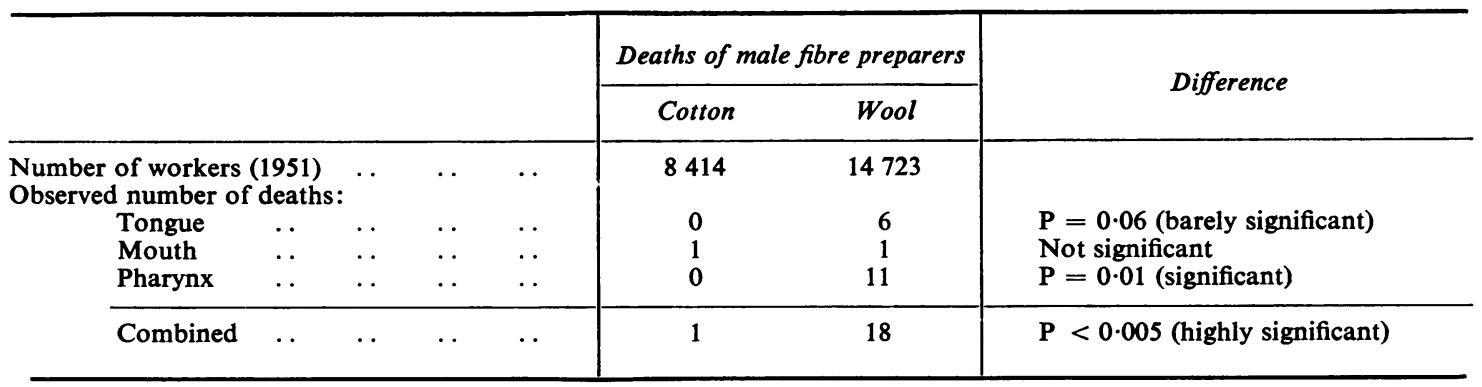

Ignoring the small number of workers with other or unknown fibres, the difference between wool and cotton is highly significant statistically and is also significant for the pharynx alone (see table above).

\section{Female textile workers}

Only five single women textile workers aged 15-64 died of oral and pharyngeal cancers in 1959-63. This number is insufficient for comparison as in Tables 2 and 3.

The 29 deaths of female workers, i.e., single women in 1959-63 and single and married women in 1970-71, have been compared in Table 7 with the numbers of female textile workers by personal occupation in 1951, as all but one of the 29 women were of working age then. For this it has been necessary to use the 1951 Census Occupation Tables (Registrar General, 1956) because the 1951 Occupational Mortality Tables classify only single women by personal occupation. This comparison is similar to that in Table 5 for male textile workers.

The differences between observed and expected numbers of deaths in Table 7 are relatively small, and none of them is statistically significant.

The effect of type of fibre cannot be considered as the only numbers available are for single women working with cotton, wool, and other fibres in 1951, and their status may have changed by the years in which deaths have been recorded, thus being lost to the analysis.

\section{Cancer registrations}

The distribution of oral and pharyngeal cancer registrations of textile workers in 1966-68 among the 13 cancer registries (Table 8) suggests either that relatively few oral cancers occurred in textile workers in the Leeds region or that there was underregistration of these cancers. The Leeds registry

TABLE 7

Deaths of Female Textile Workers, 1959-63, Aged 15-74, AND 1970-71, AGed 15 AND OVer COMPARED WITH NUMBERS WORKING IN 1951, AGED 15 AND OVER

\begin{tabular}{|c|c|c|c|c|c|c|c|}
\hline \multicolumn{2}{|c|}{ Cause of death } & $\begin{array}{c}\text { Fibre } \\
\text { preparers }\end{array}$ & $\begin{array}{c}\text { Spinners, } \\
\text { winders, } \\
\text { warpers, etc. }\end{array}$ & $\begin{array}{c}\text { Weavers, } \\
\text { knitters }\end{array}$ & $\begin{array}{l}\text { Bleachers, } \\
\text { dyers, } \\
\text { finishers }\end{array}$ & Miscellaneous & $\begin{array}{c}\text { All textile workers } \\
\text { (female })\end{array}$ \\
\hline \multicolumn{2}{|c|}{$\begin{array}{l}\text { Malignant } \\
\text { neoplasm }\end{array}$} & 35712 & 125506 & $\begin{array}{l}\text { er workin } \\
128069\end{array}$ & $\begin{array}{l}51 \text {, aged } 15 \\
17252\end{array}$ & $\begin{array}{l}\text { ad over } \\
51461\end{array}$ & 358000 \\
\hline Tongue & $\begin{array}{l}\text { O } \\
\mathrm{E} \\
\mathrm{O} / \mathrm{E}\end{array}$ & $\begin{array}{c}0 \\
0.80 \\
0\end{array}$ & $\begin{array}{c}4 \\
2 \cdot 80 \\
1 \cdot 43\end{array}$ & $\begin{array}{c}2 \\
2 \cdot 86 \\
0 \cdot 70\end{array}$ & $\begin{array}{c}0 \\
0 \cdot 39 \\
0\end{array}$ & $\begin{array}{c}2 \\
1 \cdot 15 \\
1 \cdot 74\end{array}$ & $\begin{array}{c}8 \\
8 \cdot 00\end{array}$ \\
\hline Mouth & $\begin{array}{l}\mathbf{O} \\
\mathbf{E} \\
\mathbf{O} / \mathrm{E}\end{array}$ & $\begin{array}{c}0 \\
0 \cdot 40 \\
0\end{array}$ & $\begin{array}{c}2 \\
1 \cdot 40 \\
1 \cdot 43\end{array}$ & $\begin{array}{c}2 \\
1 \cdot 43 \\
1 \cdot 40\end{array}$ & $\begin{array}{c}0 \\
0 \cdot 19 \\
0\end{array}$ & $\begin{array}{c}0 \\
0 \cdot 57 \\
0\end{array}$ & $\begin{array}{c}4 \\
3.99\end{array}$ \\
\hline Pharynx & $\begin{array}{l}\mathbf{O} \\
\mathrm{E} \\
\mathrm{O} / \mathrm{E}\end{array}$ & $\begin{array}{c}1 \\
1 \cdot 70 \\
0 \cdot 59\end{array}$ & $\begin{array}{c}6 \\
5 \cdot 96 \\
1 \cdot 01\end{array}$ & $\begin{array}{c}8 \\
6 \cdot 08 \\
1 \cdot 32\end{array}$ & $\begin{array}{c}0 \\
0.82 \\
0\end{array}$ & $\begin{array}{c}2 \\
2 \cdot 44 \\
0 \cdot 82\end{array}$ & $\begin{array}{c}17 \\
17 \cdot 00\end{array}$ \\
\hline $\begin{array}{l}\text { Tongue, } \\
\text { mouth, and } \\
\text { pharynx } \\
\text { combined }\end{array}$ & $\begin{array}{l}\mathrm{O} \\
\mathrm{E} \\
\mathrm{O} / \mathrm{E}\end{array}$ & $\begin{array}{c}1 \\
2 \cdot 89 \\
0 \cdot 35\end{array}$ & $\begin{array}{r}12 \\
10 \cdot 17 \\
1 \cdot 18\end{array}$ & $\begin{array}{r}12 \\
10 \cdot 37 \\
1 \cdot 16\end{array}$ & $\begin{array}{c}0 \\
1 \cdot 40 \\
0\end{array}$ & $\begin{array}{c}4 \\
4 \cdot 17 \\
0 \cdot 96\end{array}$ & $\begin{array}{c}29 \\
29 \cdot 00\end{array}$ \\
\hline
\end{tabular}


TABLE 8

Registrations of and Deaths from Oral and Pharyngeal Cancers in Textile Workers IN DiFFERENT Regions

\begin{tabular}{|c|c|c|c|c|c|c|c|c|c|}
\hline & & & & \multicolumn{2}{|c|}{ Leeds region } & \multicolumn{2}{|c|}{ Manchester region } & \multicolumn{2}{|c|}{ Other regions } \\
\hline & & & & $M$ & $F$ & $M$ & $F$ & $M$ & $F$ \\
\hline \multicolumn{4}{|c|}{ Number of textile workers 1951 (aged 15 and over) } & 56200 & 78300 & 86000 & 175700 & 52600 & 104200 \\
\hline \multirow[t]{2}{*}{ Registrations } & $\begin{array}{ll}1966 & \ldots \\
1967 & \ldots \\
1968 & \ldots\end{array}$ & $\begin{array}{l}. . \\
\cdots \\
\cdots\end{array}$ & $\begin{array}{l}. \\
\cdots \\
\cdots\end{array}$ & $\begin{array}{l}1 \\
0 \\
1\end{array}$ & $\begin{array}{l}2 \\
1 \\
1\end{array}$ & $\begin{array}{r}13 \\
13 \\
8\end{array}$ & $\begin{array}{l}5 \\
4 \\
5\end{array}$ & $\begin{array}{l}3 \\
1 \\
6\end{array}$ & $\begin{array}{l}5 \\
2 \\
2\end{array}$ \\
\hline & $1966-68$ & . & . & 2 & 4 & 34 & 14 & 10 & 9 \\
\hline \multirow[t]{2}{*}{ Deaths } & $\begin{array}{l}1959-63 \\
1970-71\end{array}$ & $\begin{array}{l}. . \\
.\end{array}$ & $\begin{array}{l}. . \\
.\end{array}$ & $\begin{array}{r}25 \\
4\end{array}$ & $\begin{array}{l}3 \\
3\end{array}$ & $\begin{array}{r}22 \\
7\end{array}$ & $\begin{array}{r}3 \\
16\end{array}$ & $\begin{array}{l}9 \\
5\end{array}$ & $\begin{array}{l}2 \\
2\end{array}$ \\
\hline & , 1970-71 & .. & .. & 29 & 6 & 29 & 19 & 14 & 4 \\
\hline
\end{tabular}

covers one of the main textile regions (mostly wool), the other main region being Manchester (mostly cotton). The remaining 11 regions include the only other concentration of textile industry in England and Wales, the Nottingham and Leicester area (mostly knitting of all fibres and lace).

It is possible that at that time few of the Leeds registrations had occupation recorded. This is confirmed by figures supplied by the Registrar General for all oral and pharyngeal cancer registrations in the Leeds region, 1966-68. One hundred and sixty of the 257 male registrations $(62 \%)$ and 140 of the 175 female registrations $(80 \%)$ were classified in occupational category 27-inadequately described occupations. This together with the possibility that the registrations in all the regions did not include all cases of oral and pharyngeal cancer renders the registrations for 1966-68 of little value for our purpose.

\section{Discussion}

The excess of oral and pharyngeal cancers in male textile workers compared with the general population was found in all the occupational sub-groups with the exception of weavers and knitters (Table 3). The excess is, however, much greater in fibre preparers than in the other occupations (Tables 3 and 5). Many textile processes are dusty to some extent but the processes employed in fibre preparing ${ }^{1}$ are the dustiest, and particularly those used in cleaning the raw fibres. The extraneous substances removed at

\footnotetext{
1 Fibre preparing or 'gilling' in the worsted industry is a process applied to longer staple wools before combing (Brearley, 1964). In the present study the term is used in a much wider sense and includes all sorting, opening, blending, and cleaning of raw fibres up to but not including spinning.
}

this stage are many and varied. Brearley (1965) lists the following materials as being present in raw wool: natural secretions and excretions, animal parasites, vegetable burrs and grass, soil, tar and paint, branding fluids, sheep-dips and salves. The impurities account for from $20 \%$ to as much as $55 \%$ of the raw wool. Wool fibre obtained from hides may contain lime. The methods employed in cleaning often include breaking down the non-fibrous material into fine particles, i.e., producing dust. Airborne dust in the later processes of carding and combing is mostly wool-fibre tips and some wool scales.

Rag sorting and rag grinding (tearing rags into individual fibres) are dusty jobs. In rag grinding smoke as well as dust is often produced by combustion of oil and fibre caused by heat generated by friction. Some oiling of wool is done during fibre preparing, but the oil used is usually vegetable, not mineral oil.

It should be noted that the wool industry is changing very rapidly at present. For example, metallic wire is replacing card-fillet in carding. Little fettling (a very dusty job) is required as metallic wire does not need grinding and does not fill up with fibre.

Raw cotton also contains vegetable matter (cotton seeds and fragments of broken leaf, bract, and stalk from the plant) and mineral matter from the soil, though the proportion of trash $(1-15 \%)$ is much less than in raw wool (Lord, 1961). These materials produce dust during fibre preparing, particularly carding, which is associated with byssinosis (Roach and Schilling, 1960).

The occupations of the male fibre preparers who died of oral and pharyngeal cancers in 1959-63 and 1970-71 are classified roughly in Table 9 according to the dustiness of the job, the degree of dustiness 
TABLE 9

Dustiness of Jobs of Male Fibre Preparers who died of Oral and Pharyngeal Cancers, 1959-63, 1970-71

\begin{tabular}{|c|c|c|c|}
\hline $\begin{array}{c}\text { Cause of death } \\
\text { Malignant neoplasm }\end{array}$ & $\begin{array}{l}\text { Job } \\
\text { (age at death in parentheses) }\end{array}$ & Fibre & Description of job \\
\hline Tongue (ICD 141) & $\begin{array}{l}\text { Fettler (47) } \\
\text { Mixer, woollen mill (59) } \\
\text { Woollen willeyer (61) } \\
\text { Wool sorter (72) } \\
\text { Wool sorter (82) } \\
\text { Woollen scourer (71) } \\
\text { Card hand at twine factory (70) }\end{array}$ & $\begin{array}{l}\text { Wool } \\
, " \\
", \\
\text { Other }\end{array}$ & $\begin{array}{c}\text { Very dusty } \\
\text { ", } \\
, \\
\text { Dusty } \\
\text { ", }\end{array}$ \\
\hline Floor of mouth (ICD 143) & Card jobber, wool combing (61) & Wool & Some dust \\
\hline $\begin{array}{l}\text { Mouth, other parts and unspecified } \\
\text { (ICD 144) }\end{array}$ & Stripper and grinder, carding (71) & Cotton & Very dusty \\
\hline Oropharynx (ICD 145) & $\begin{array}{l}\text { Woollen willeyer (73) } \\
\text { Sorter (shoddy mill) }\end{array}$ & $\begin{array}{c}\text { Wool } \\
, "\end{array}$ & $\begin{array}{c}\text { Very dusty } \\
,\end{array}$ \\
\hline Nasopharynx (ICD 146) & $\begin{array}{l}\text { Rag grinder at shoddy mill (61) } \\
\text { Fettler in woollen mill (69) } \\
\text { Wool grader (70) } \\
\text { Foreman carder (48) } \\
\text { Comber }(51) \\
\text { Backwash minder }{ }^{1} \text {, woollen mill (61) }\end{array}$ & $\begin{array}{l}\text { Wool } \\
\text { " } \\
" \\
" \\
"\end{array}$ & $\begin{array}{l}\text { Very dusty } \\
\text { ", } \\
\text { Some dust } \\
\text { Not dusty }\end{array}$ \\
\hline Hypopharynx (ICD 147) & $\begin{array}{l}\text { Carder (86) } \\
\text { Gill box minder (wool combing) } \\
\text { Foreman comber ( } 68 \text { ) } \\
\text { Rayon mill trapper (mixing) }\end{array}$ & $\begin{array}{l}\text { Cotton? } \\
\text { Wool } \\
\text { Other }\end{array}$ & $\begin{array}{l}\text { Dusty } \\
\text { Some dust } \\
\text { Dusty }\end{array}$ \\
\hline Pharynx unspecified (ICD 148) & Textile feeder & Wool & Some dust \\
\hline
\end{tabular}

${ }^{1}$ A relatively sheltered job. Backwash minders have usually had a more exacting job in the industry, which may have been dusty and which they could no longer cope with.

being simply relative. The proportion of very dusty and dusty jobs is high.

Some of the jobs classified as miscellaneous are very dusty, which may account for some of the excess in this occupational sub-group (Table 5). Of the 13 male deaths in this sub-group, three were cotton-loom sweepers and one a wool-felt worker.

There may well be an association between the inhalation of dust by textile workers and oral and pharyngeal cancers. The evidence of an excess of adenocarcinomas of the nasal cavity and sinuses in workers in the textile and clothing industries found by Acheson et al. (1972) has already been mentioned. Recently Stell and McGill (1973) have reported a highly significant excess of squamous-cell carcinoma of the larynx in asbestos workers.

It is probable that the higher excess of cancers sited in the tongue as compared with the mouth is due to the closer association between tongue and pharynx. Nearly $60 \%$ of the cancers of the tongue were described as being sited in the posterior third or the base.

The excess of cancers in the mouth might possibly be associated with tobacco chewing. However, there is no tradition of this practice in any part of the textile industry, although its occasional use cannot be excluded.

In the 73 registrations $58 \%$ of the malignancies were described as squamous-celled and $34 \%$ were recorded only as carcinomas. The proportions in males and females were very similar.

\section{Conclusion}

Although the comparisons based on male deaths present strong evidence of an excess of oral and pharyngeal cancers in wool fibre preparers it should be noted that they are based essentially on a single set of numerators compared with various denominators. Furthermore, the information on the mortality of female textile workers from these cancers is inadequate, as also are the data available so far from registration. Moreover, occupations recorded on death certificates are not always the best indicators of occupational history throughout working life.

A continuation of this study by a survey in which 
patients suffering from oral and pharyngeal cancers are interviewed with regard to their occupational history and smoking habits has already been initiated in the Manchester region. It is hoped to extend this to the Leeds region, thus covering the two main textile regions of England and Wales and including particularly cotton and wool and also other fibres. These surveys will have the added advantage of providing more accurate information on site and more detailed histological data.

Thanks are due to Dr. A. M. Adelstein, Chief Medical Statistician, Office of Population Censuses and Surveys, for making available the individual records of deaths and registrations of oral and pharyngeal cancers in textile workers; to Dr. I. Leck, Manchester Regional Cancer Registry, for advice on registrations; to Dr. S. M. Jackson, consultant radiotherapist, Christie Hospital, Manchester, for discussions on sites and types of cancers; and to Mr. R. J. Wilson and Mr. R. Bownass, Wool Industries Research Association, for information on occupations in the woollen and worsted industries.

\section{References}

Acheson, E. D., Cowdell, R. H., and Rang, Elizabeth (1972). Adenocarcinoma of the nasal cavity and sinuses in England and Wales, British Journal of Industrial Medicine, 29, 21-30.
Brearley, A. (1964). Worsted, p. 35. Pitman, London. (1965). The Woollen Industry, p. 28. Pitman, London.

Easson, E. C. and Russell, M. H. (1968). The Curability of Cancer in Various Sites, p. 26. Pitman Medical Publishing Co., London.

Lord, E. (1961). Manual of Cotton Spinning II, Part 1, The Characteristics of Raw Cotton, p. 234. Textile Institute and Butterworths, Manchester and London.

Office of Population Censuses and Surveys (1972). Studies on Medical and Population Subjects No. 23Oral Cancer in England and Wales, edited by Binnie, W. H., Cawson, R. A., Hill, G. B., and Soaper, A. E. HMSO, London.

Registrar General (1956). Census 1951 Occupation Tables. HMSO, London.

(1958). Decennial Supplement, England and Wales, 1951, Occupational Mortality Part II, vol. 2. HMSO, London.

(1971). Decennial Supplement, England and Wales, 1961, Occupatioanl Mortality Tables. HMSO, London.

Roach, S. A. and Schilling, R. S. F. (1960). A clinical and environmental study of byssinosis in the Lancashire cotton industry. British Journal of Industrial Medicine, 17, 1-9.

Stell, P. M. and McGill, T. (1973). Asbestos and laryngeal carcinoma. Lancet, 2, 416-417.

Received for publication 8 October, 1973.

Accepted for publication 4 February, 1974. 